\title{
Performance of Early Maturing Lentil Cultivars in New Alluvial Zone of West Bengal
}

\author{
Ananya Ghosh ${ }^{1 *}$, Md. Hasim Reja ${ }^{1}$, Arpita Nalia ${ }^{1}$, Bishal Mukherjee ${ }^{1}$, \\ Sagar Moitra ${ }^{2}$, Ashutosh Sarker ${ }^{3}$ and Rajib Nath ${ }^{1}$
}

${ }^{1}$ Department of Agronomy, Bidhan Chandra Krishi Viswavidyalaya, Mohanpur, Nadia- 741252, West Bengal, India

${ }^{2}$ DepartmentofAgronomy, M.S. Swaminathan School of Agriculture, Centurion University of

Technology and Management, Paralakhemund-761211, India

${ }^{3}$ Food Legume Breeder and Regional Coordinator, ICARDA-South Asian China Regional

Programme, NASC Complex, CGIAR Building, New Delhi, India

*Corresponding author

\section{A B S T R A C T}

\begin{tabular}{|l|}
\hline Key w o r d s \\
Pulse, Cultivar, \\
$\begin{array}{l}\text { Phenology, Rice- } \\
\text { fallow, Yield }\end{array}$ \\
\hline Article Info \\
\hline $\begin{array}{l}\text { Accepted: } \\
\text { 17 June } 2020 \\
\text { Available Online: } \\
\text { 10 July 2020 }\end{array}$ \\
\hline
\end{tabular}

A field experiment was conducted to assess sixteen lentil cultivars in terms of phenology, yield attributing characters and yield in randomized block design at district seed farm, AB block, BCKV, West Bengal, during rabi seasons of 2015-16 and 2016-17. The results of two the years experiment revealed that phenological characteristics, yield attributing characters and yield varied significantly during both the years of experimentation. Phenological development (flower initiation, 50\% flowering, 100\% flowering and maturity) was fastest with cultivar ILL 8006. Other cultivars like ILL 10805, ILL 10971, ILL 10921 ILL 10803, ILL 10961 and ILL 10951 were also early maturing type. Maximum seed yield was noted with ILL 10803 (1729 $\mathrm{kg} \mathrm{ha}^{-1}$ ) followed by ILL 10805 (1665 kg ha $\mathrm{kg}^{-1}$ ) and ILL $10951\left(1623 \mathrm{~kg} \mathrm{ha}^{-1}\right)$ by attributing higher number of pods per plant and test weight, whereas, lowest was recorded with ILL $8006\left(1114 \mathrm{~kg} \mathrm{ha}^{-1}\right)$. Cultivar ILL 10803, ILL 10805 and ILL 10951 has a promising potential in New Alluvial Zone of West Bengal not only due to their higher yield potential but also their early maturing habit.

\section{Introduction}

Today's agriculture, specifically the rainfed agriculture is facing an immense challenge due to delayed monsoon, uneven distribution of rainfall and ultimately water crisis in critical growth period of crop. These monsoon vagaries delayed the sowing of kharif rice, the mostly grown Indian crop. Coupled with delayed sowing, long duration rice varieties obstruct rabi sowing and promotes rice fallow area due to various biotic and abiotic stresses (Ali and Kumar, 2009 and Ghosh et al., 2019). In addition to this, cereal based cropping system deteriorates soil health by heavy withdrawal of nutrients. Incorporation of a rabi pulse crop in rice-based cropping system would be convenientto serve the 
demand of increasing the cropping intensity and restoration of soil fertility (Ali, 2014). In conjunction with a lot of advantages in human and soil health, lentil can thrive well in marginal environment with residual soil moisture of harvested paddy field (Nalia et al., 2019). But sowing of existing long duration lentil varieties can expose the crop in severe terminal heat and drought stress during its maturity leading to poor seed yield and quality. Identification and adaptation of short duration varieties with the ability to escape the terminal stresses is a key to intensify the rice fallow area effectively. Considering all these facts, an attempt has been made to evaluate the suitable genotype of lentil among the sixteen in terms of phenological development and yield in New Alluvial Zone of West Bengal.

\section{Materials and Methods}

The experiment was carried out in two consecutive rabi seasons of 2015-16 and 2016-17 at the District Seed Farm, AB block, Kalyani, Bidhan Chandra Krishi Viswavidyalaya, Nadia, West Bengal, India. The experimental soil was sandy loam in texture with $\mathrm{pH} 7.3$, EC $0.18 \mathrm{dS} \mathrm{m}^{-1}$, organic carbon $0.56 \%$, available $\mathrm{N} 231.28 \mathrm{~kg}$ ha ${ }^{1}, \mathrm{P}_{2} \mathrm{O}_{5} \quad 34.51 \mathrm{~kg} \mathrm{ha}{ }^{-1}$, and available $\mathrm{K}_{2} \mathrm{O}$ $188.83 \mathrm{~kg} \mathrm{ha}^{-1}$. The experiment was laid out in a factorial randomized block design replicated thrice comprising sixteen lentil genotypes (ILL 8006, ILL10951, ILL 10971, ILL 10803, ILL 10971, ILL 10802, ILL 10893, ILL 10921, ILL 10805, ILL 10803, ILL 10961, ILL 10922, ILL 10897, ILL 10893, ILL 10921 and ILL 10951). The genotypes were supplied by ICARDA, Rabat, Morocco under BCKV-ICARDA lentil work place to test under rice fallows of West Bengal. Seeds were sown maintaining a row distance of $25 \mathrm{~cm}$ in line after harvesting of monsoon rice.
The recommended dose of fertilizers i.e. $\mathrm{N}: \mathrm{P}_{2} \mathrm{O}_{5}: \mathrm{K}_{2} \mathrm{O}::$ 20:40:40 $\mathrm{kg} \mathrm{ha}^{-1}$ were applied at the time of land preparation. The data of phenology, yield attribute and yield were recorded from randomly selected five plants of each plot.

\section{Results and Discussion}

Lentil cultivars differ significantly in terms of phenological development like flower initiation, $50 \%$ flowering, $100 \%$ flowering and days to maturity (Table 1). The cultivars came at their reproductive stages in between 42 to 68 DAS in 2015-16 and 47 to 70 DAS in 2016-17.

According to the pooled result first flower was appeared in cultivar ILL 8006 (44 DAS). Not only flower initiation but also $50 \%$ flowering (56 DAS), 100\% flowering (64 DAS) and maturity (91 DAS) was earliest with ILL 8006.All other cultivars except ILL 10951 (65 DAS), ILL 10897 (66 DAS) and ILL 10921(69 DAS) succeeded to their reproductive stage within 60 DAS and consequently matures in 114 DAS. ILL 10951, ILL 10897 and ILL 10921 took 121, 124 and 128 DAS respectively to mature.

Due to variation in genotypic character and to a lesser extent differential nutrient and water mining from soil leads to alteration in yield and yield attributing characters. Number of primary branches ranged between 2.4 to 3.8 and 2.1 to 4.4 in 2015-16 and 2016-17 respectively (Table 2). Pooled data over two years recorded highest number of branches per plant with ILL 10803 (3.7). Pods per plant varied significantly among the cultivars with maximum in ILL 10951 for both the years of experiment (112.2 and 101.9 in 2015-16 and 2016-17 respectively). 
Table.1 Phonological characteristics of lentil genotypes

\begin{tabular}{|c|c|c|c|c|c|c|c|c|c|c|c|c|}
\hline \multirow[t]{2}{*}{ Genotypes } & \multicolumn{3}{|c|}{ Days to first flower initiation } & \multicolumn{3}{|c|}{ Days to $50 \%$ flowering } & \multicolumn{3}{|c|}{ Days to $100 \%$ flowering } & \multicolumn{3}{|c|}{ Days to maturity } \\
\hline & $2015-16$ & 2016-17 & Pooled & $2015-16$ & 2016-17 & Pooled & $2015-16$ & 2016-17 & Pooled & $2015-16$ & 2016-17 & Pooled \\
\hline ILL 8006 & 42 & 47 & 44 & 54 & 59 & 56 & 62 & 66 & 64 & 90 & 93 & 91 \\
\hline ILL10951 & 49 & 47 & 48 & 58 & 55 & 56 & 68 & 62 & 65 & 108 & 101 & 104 \\
\hline ILL 10971 & 52 & 51 & 51 & 61 & 60 & 60 & 70 & 71 & 71 & 100 & 101 & 100 \\
\hline ILL 10803 & 59 & 50 & 54 & 66 & 64 & 65 & 75 & 72 & 73 & 104 & 100 & 102 \\
\hline ILL 10971 & 56 & 59 & 57 & 64 & 69 & 66 & 74 & 78 & 76 & 106 & 107 & 106 \\
\hline ILL 10802 & 50 & 56 & 53 & 59 & 65 & 62 & 70 & 79 & 75 & 110 & 105 & 107 \\
\hline ILL 10893 & 64 & 62 & 63 & 75 & 73 & 74 & 85 & 84 & 84 & 113 & 112 & 112 \\
\hline ILL 10921 & 55 & 52 & 53 & 65 & 64 & 64 & 75 & 71 & 73 & 103 & 99 & 101 \\
\hline ILL 10805 & 62 & 68 & 65 & 73 & 78 & 75 & 83 & 87 & 85 & 112 & 116 & 114 \\
\hline ILL 10803 & 61 & 64 & 63 & 70 & 73 & 71 & 81 & 80 & 80 & 110 & 119 & 114 \\
\hline ILL 10961 & 52 & 55 & 53 & 61 & 66 & 63 & 71 & 75 & 73 & 102 & 104 & 103 \\
\hline ILL 10922 & 50 & 55 & 53 & 58 & 68 & 63 & 67 & 77 & 72 & 116 & 105 & 110 \\
\hline ILL 10897 & 66 & 67 & 66 & 74 & 80 & 77 & 85 & 91 & 88 & 128 & 119 & 124 \\
\hline ILL 10893 & 63 & 58 & 60 & 73 & 69 & 71 & 84 & 79 & 81 & 113 & 107 & 110 \\
\hline ILL 10921 & 67 & 70 & 69 & 78 & 82 & 80 & 90 & 95 & 92 & 129 & 128 & 128 \\
\hline ILL 10951 & 68 & 62 & 65 & 79 & 71 & 75 & 91 & 82 & 86 & 126 & 117 & 121 \\
\hline S. Em ( $( \pm)$ & 2.12 & 2.37 & 1.31 & 2.69 & 3.04 & 1.64 & 3.11 & 3.44 & 2.14 & 4.84 & 3.18 & 3.29 \\
\hline $\begin{array}{c}\text { CD } \\
(p=0.05)\end{array}$ & 6.36 & 7.09 & 3.94 & 8.06 & 9.13 & 4.92 & 9.33 & 10.31 & 6.41 & 14.52 & 9.53 & 9.76 \\
\hline
\end{tabular}


Table.2 Yield and yield attributing characters of lentil genotypes

\begin{tabular}{|c|c|c|c|c|c|c|c|c|c|c|c|c|}
\hline \multirow[t]{2}{*}{ Genotypes } & \multicolumn{3}{|c|}{$\begin{array}{l}\text { Number of primary } \\
\text { branches per plant }\end{array}$} & \multicolumn{3}{|c|}{ Number of pods per plant } & \multicolumn{3}{|c|}{1000 seeds weight $(\mathrm{g})$} & \multicolumn{3}{|c|}{ Yield (kg/ha) } \\
\hline & 2015-16 & 2016-17 & Pooled & 2015-16 & 2016-17 & Pooled & $2015-16$ & 2016-17 & Pooled & 2015-16 & 2016-17 & Pooled \\
\hline ILL 8006 & 2.8 & 2.3 & 3.0 & 61.4 & 51.3 & 56.3 & 19.40 & 21.30 & 20.35 & 1099 & 1130 & 1114 \\
\hline ILL10951 & 2.8 & 2.6 & 3.2 & 53.7 & 69.1 & 61.4 & 19.55 & 26.50 & 23.02 & 1178 & 1261 & 1220 \\
\hline ILL 10971 & 2.4 & 3 & 2.8 & 63 & 70.0 & 66.5 & 25.80 & 30.30 & 28.05 & 1405 & 1466 & 1436 \\
\hline ILL 10803 & 3.4 & 3.4 & 3.7 & 92.3 & 74.9 & 83.6 & 23.25 & 19.60 & 21.42 & 1433 & 1451 & 1442 \\
\hline ILL 10971 & 2.9 & 4.3 & 3.3 & 97 & 77.0 & 87.0 & 22.40 & 23.30 & 22.85 & 1522 & 1563 & 1542 \\
\hline ILL 10802 & 3.0 & 2.5 & 2.9 & 65.8 & 84.8 & 75.3 & 22.65 & 35.40 & 29.02 & 1524 & 1609 & 1566 \\
\hline ILL 10893 & 2.9 & 3.2 & 2.9 & 71 & 45.4 & 58.2 & 29.10 & 29.40 & 29.25 & 1542 & 1481 & 1511 \\
\hline ILL 10921 & 3.0 & 4.4 & 3.4 & 101.4 & 89.6 & 95.5 & 29.00 & 30.70 & 29.85 & 1490 & 1431 & 1461 \\
\hline ILL 10805 & 2.7 & 3.2 & 2.8 & 80.9 & 82.6 & 81.7 & 27.25 & 32.20 & 29.72 & 1626 & 1704 & 1665 \\
\hline ILL 10803 & 3.2 & 2.9 & 3.1 & 88.25 & 85.1 & 86.7 & 30.70 & 31.40 & 31.05 & 1683 & 1776 & 1729 \\
\hline ILL 10961 & 3.2 & 3.6 & 3.1 & 85.7 & 87.1 & 86.4 & 27.85 & 29.00 & 28.42 & 1365 & 1327 & 1346 \\
\hline ILL 10922 & 3.6 & 3.7 & 3.4 & 69.6 & 64.3 & 66.9 & 20.25 & 24.40 & 22.32 & 1146 & 1214 & 1180 \\
\hline ILL 10897 & 3.8 & 2.5 & 3.2 & 64.8 & 61.5 & 63.2 & 27.85 & 30.50 & 29.17 & 1524 & 1595 & 1559 \\
\hline ILL 10893 & 2.9 & 2.7 & 3.0 & 64.1 & 58.7 & 61.4 & 22.45 & 23.60 & 23.02 & 1355 & 1222 & 1288 \\
\hline ILL 10921 & 3.5 & 3.1 & 3.2 & 96.1 & 88.6 & 92.3 & 27.70 & 28.40 & 28.05 & 1357 & 1286 & 1321 \\
\hline ILL 10951 & 2.6 & 4.3 & 3.3 & 112.2 & 101.9 & 107.0 & 28.20 & 31.10 & 29.65 & 1563 & 1684 & 1623 \\
\hline S. $\operatorname{Em}( \pm)$ & 0.46 & 0.51 & 0.36 & 6.28 & 7.89 & 5.64 & 2.40 & 1.90 & 2.7 & 109.55 & 83.80 & 88.50 \\
\hline $\begin{array}{c}\text { CD } \\
(p=0.05)\end{array}$ & NS & NS & NS & 18.82 & 23.67 & 16.90 & NS & NS & NS & 328.44 & 251.23 & 265.34 \\
\hline
\end{tabular}


As per pooled analysis, ILL 10921 (95.5), ILL 10921 (92.3), ILL 10971 (87.0), ILL 10803 (86.7), ILL 10803 (83.6) and ILL 10805 (81.7) also registered significantly good number of pods per plant. Maximum test weight was found with ILL 10803 $(31.05 \mathrm{~g})$ followed by ILL $10921(29.85 \mathrm{~g})$ due to their bold seeded character (macrosperma type seed), whereas lowest test weight was observed in ILL 8006 (20.35g). Productivity of these sixteen cultivars differed to the tune of 1146 to $1683 \mathrm{~kg} \mathrm{ha}^{-1}$ during 2015-16 and 1130 to $1776 \mathrm{~kg} \mathrm{ha}^{-1}$ during 2016-17. Based on pooled analysis, maximum seed yield was recorded with ILL $10803\left(1729 \mathrm{~kg} \mathrm{ha}^{-1}\right)$ followed by ILL $10805\left(1665 \mathrm{~kg} \mathrm{ha}^{-1}\right)$, ILL $10951\left(1623 \mathrm{~kg} \mathrm{ha}^{-1}\right)$ and lowest was recorded with ILL 8006 (1114 $\left.\mathrm{kg} \mathrm{ha}^{-1}\right)$.

From the result we noticed that the lentil cultivars differed significantly in terms of flower initiation, 50\% flowering, $100 \%$ flowering and days to maturity because, being a non-synchronous crop it doesn't possess any marked boundary between vegetative and reproductive stage (Rejaet al., 2017). The result of the investigation are also in conformity with Roy et al., 2009, who recorded a variation in test weight among four lentil cultivars grown under West Bengal condition. Superiority of ILL 10803, ILL 10805 and ILL 10951 in terms of seed yield can be attributed to their good number of pods per plant and test weight which substantiated to the findings of Maurya and Rathi (2000), Layek et al., (2012) and Layek et al., (2014). Considering the most important factor of yield and the phenology of these sixteen cultivars it can be concluded that ILL 10803, ILL 10805 and ILL 10951 showed promising potential in the rice fallow areas of New Alluvial Zone of West Bengal.

\section{References}

Ali, M., Kumar, S.2009.Major technological advances in pulses- Indian scenario. In: Milestones in Food Legumes Research, (Eds. Masood Ali and Shiv Kumar). Indian Institute of Pulses Research, Kanpur, India, 20.

Ali, M.2014.Improving productivity of pulses in rice fallows. Indian Farming. 63(12):17-19.

Reja, M.H., Mandi, S.K., Kundu, M.K., Nath, R., Goswami, S.B. 2017. Performance of different lentil varieties in new alluvial zone of West Bengal. The Bioscan. 12(3):1673- 1676.

Maurya, B.M. and Rathi, K.S. 2000. Growth and development of soybean as influenced by intercropping with pigeonpea and phosphorus level. Gujarat Agricultural University Research Journal. 26(1): 1-5.

Layek, J., Shivakumar, B.G., Rana, D.S., Munda, S. and Lakshman, K. 2012. Growth pattern, physiological indices and productivity of different soybean (Glycine max) based intercrops as influenced by nitrogen nutrition. Indian Journal of Agronomy. 57(4): 349-356.

Layek, J.A., Chowdhury, S.A., Ramkrushna, G.I., Das, A. 2014.Evaluation of different lentil cultivars in lowland rice fallow under no-till system for enhancing cropping intensity and productivity. Indian Journal of Hill Farming.27(2): 4-9.

Ghosh, A., Reja, M.H., Nalia, A., Mukherjee, B., Nath, R. and Sarker, A. 2019. Evaluation of extra early lentil varieties in rice-fallow areas of West Bengal. The Pharma Innovation Journal. 8(4): 312-314.

Nalia, A., Reja, M.H., Ghosh, A., Mukherjee, B., Nath, R., Dixit, H.K. and Sarkar, A. 2019.Performance of short duration lentil genotypes in the rice fallows of new alluvial zone of West Bengal. Journal of Food legumes. 32(2): 75-7. 


\section{How to cite this article:}

Ananya Ghosh, Md. Hasim Reja, Arpita Nalia, Bishal Mukherjee, Sagar Moitra, Ashutosh Sarker and Rajib Nath. 2020. Performance of Early Maturing Lentil Cultivars in New Alluvial Zone of West Bengal. Int.J.Curr.Microbiol.App.Sci. 9(07): 1776-1781. doi: https://doi.org/10.20546/ijcmas.2020.907.203 